\title{
Genocide in Cambodia
}




\section{Pennsylvania Studies in Human Rights}

Bert B. Lockwood, Jr., Series Editor

A complete list of books in the series

is available from the publisher. 


\section{Genocide in Cambodia}

\section{Documents from the Trial of \\ Pol Pot and leng Sary}

\section{Edited by}

HOWARD J. DE NIKE, JOHN QUIGLEY, and KENNETH J. ROBINSON with the assistance of

HELEN JARVIS and NEREIDA CROSS

\section{PENN}

University of Pennsylvania Press

Philadelphia 
Copyright (C) 2000 University of Pennsylvania Press

All rights reserved

Printed in the United States of America on acid-free paper

10987654321

Published by

University of Pennsylvania Press

Philadelphia, Pennsylvania 19104-4011

Library of Congress Cataloging-in-Publication Data

Pol Pot.

Genocide in Cambodia : documents from the trial of Pol Pot and Ieng Sary / edited by Howard J. De Nike, John Quigley, and Kenneth J. Robinson, with the assistance of Helen Jarvis and Nereida Cross.

p. cm. - (Pennsylvania studies in human rights)

Includes bibliographical references and index.

ISBN 0-8122-3539-8 (alk. paper)

1. Pol Pot-Trials, litigation, etc. 2. Ieng Sary-Trials, litigation, etc. 3. Trials (Genocide) - Cambodia. I. Ieng Sary. II. De Nike, Howard J. III. Quigley, John B. IV Robinson, Kenneth J. (Kenneth Jay). V. Cambodia. Tribunal populaire révolutionnaire. VI. Title. VII. Series.

KNM41.P65 P65 2000

$345.596^{\prime} 0251-\mathrm{dc} 21$

99-055971 